\title{
Plasticity of Binocularity and Visual Acuity Are Differentially Limited by Nogo Receptor
}

\author{
Céleste-Élise Stephany, ${ }^{1 \star}$ Leanne L.H. Chan, ${ }^{1,2 \star}$ Sherveen N. Parivash, ${ }^{1}$ Hilary M. Dorton, ${ }^{1}$ Mariel Piechowicz, ${ }^{3}$ \\ (D) Shenfeng Qiu, ${ }^{3}$ and ${ }^{(1)}$ Aaron W. McGee ${ }^{1}$ \\ ${ }^{1}$ Developmental Neuroscience Program, Saban Research Institute, Children's Hospital Los Angeles, Department of Pediatrics, Keck School of Medicine, \\ University of Southern California, Los Angeles, California 90027, ${ }^{2}$ Centre for Biosystems, Neuroscience, and Nanotechnology, Department of Electronic \\ Engineering, City University of Hong Kong, Kowloon, Hong Kong SAR, China, and ${ }^{3}$ Department of Basic Medical Sciences, University of Arizona College of \\ Medicine-Phoenix, Phoenix, Arizona 85004
}

The closure of developmental critical periods consolidates neural circuitry but also limits recovery from early abnormal sensory experience. Degrading vision by one eye throughout a critical period both perturbs ocular dominance (OD) in primary visual cortex and impairs visual acuity permanently. Yet understanding how binocularity and visual acuity interrelate has proven elusive. Here we demonstrate the plasticity of binocularity and acuity are separable and differentially regulated by the neuronal nogo receptor 1 (NgR1). Mice lacking NgR1 display developmental OD plasticity as adults and their visual acuity spontaneously improves after prolonged monocular deprivation. Restricting deletion of NgR1 to either cortical interneurons or a subclass of parvalbumin (PV)-positive interneurons alters intralaminar synaptic connectivity in visual cortex and prevents closure of the critical period for OD plasticity. However, loss of NgR1 in PV neurons does not rescue deficits in acuity induced by chronic visual deprivation. Thus, NgR1 functions with PV interneurons to limit plasticity of binocularity, but its expression is required more extensively within brain circuitry to limit improvement of visual acuity following chronic deprivation.

Key words: Cre recombinase; mice; nogo receptor; ocular dominance plasticity; parvalbumin; visual acuity

\section{Introduction}

In the mammalian brain, the flexibility of neuronal functional properties and synaptic connectivity diminishes as development concludes. The reduced plasticity of the adult brain limits recovery from amblyopia, a disorder caused by discordant vision during childhood. Amblyopia comprises several deficits in spatial vision including reduced stereopsis and lower visual acuity of the affected eye (Webber and Wood, 2005). In animal models of amblyopia, closing one eye throughout an early sensitive or "critical" period similarly disrupts binocularity and impedes the maturation of acuity by the deprived eye (Hubel and Wiesel, 1970; Dräger, 1978; Giffin and Mitchell, 1978; Prusky and Douglas, 2003; Morishita and Hensch, 2008). Analogous to clinical find-

\footnotetext{
Received Feb. 6, 2014; revised June 9, 2014; accepted July 22, 2014.

Author contributions: C.-E.S., L.L.H.C., S.Q., and A.W.M. designed research; C.-E.S., L.L.H.C., S.N.P., H.M.D., S.Q., and A.W.M. performed research; C.E.S., L.L.H,C., S.N.P., H.M.D., M.P., S.Q., and A.W.M. analyzed data; C.-E.S., S.Q., and A.W.M. wrote the paper.

This research is supported by the National Eye Institute (1R01EY021580) and a Research Development Career Award from Children's Hospital Los Angeles. A.W.M. is the recipient of a Career Award in the Biomedical Sciences (CABS) from the Burroughs Wellcome Fund.

The authors declare no competing financial interests.

${ }^{*}$ C.E.S. and L.L.H.C. contributed equally to this work.

Correspondence should be addressed to either of the following: Shenfeng Qiu, Department of Basic Medical Sciences, University of Arizona College of Medicine-Phoenix, Phoenix, AZ85004. E-mail: sqiu@email.arizona.edu; or Aaron W. McGee, Developmental Neuroscience Program, Saban Research Institute, Children's Hospital Los Angeles, Department of Pediatrics, Keck School of Medicine, University of Southern California, Los Angeles, CA 90072, E-mail: amcgee@usc.edu.

DOI:10.1523/JNEUROSCI.0545-14.2014

Copyright $\odot 2014$ the authors $\quad 0270-6474 / 14 / 3411631-10 \$ 15.00 / 0$
}

ings (Scheiman et al., 2005; Maurer and Hensch, 2012), deficits in ocular dominance (OD) and acuity persist if normal vision is restored after the critical period (Wiesel and Hubel, 1965; Prusky and Douglas, 2003; Morishita and Hensch, 2008). Although the adverse effects of abnormal vision during the critical period have been known for decades, investigating the relationship between the plasticity of eye dominance and acuity remains a challenge.

Multiple lines of evidence correlate OD plasticity with visual acuity during the critical period. A balance between excitatory and inhibitory neurotransmission (E/I balance) is essential for initiating the critical period for both OD plasticity and the maturation of acuity (Hensch, 1998; Huang et al., 1999; Fagiolini and Hensch, 2000; Levelt and Hübener, 2012). Several manipulations of visual experience that affect OD plasticity also perturb visual acuity. For example, dark rearing delays the onset of both the critical period for OD plasticity and the development of visual acuity (Fagiolini et al., 1994), while environmental enrichment accelerates the opening of the critical period and maturation of visual acuity (Huang et al., 1999; Sale et al., 2004). In addition, disparate pharmacologic and environmental manipulations that alter E/I balance in visual cortex both enhance OD plasticity in the adult and improve visual acuity following long-term monocular deprivation (LTMD) (Morishita and Hensch, 2008; Levelt and Hübener, 2012). Where and how these interventions modify cortical circuitry to restore OD plasticity and increase visual acuity is unclear, but recent studies have demonstrated that parvalbumin-positive (PV) inhibitory neurons are key regulators 
of visual plasticity (Fagiolini et al., 2004; Katagiri et al., 2007; Kuhlman et al., 2013).

The deposition of perineuronal nets and myelination also contributes to closing the critical period. These modifications to extracellular environment present several inhibitors of anatomical plasticity, including chondroitin sulfate proteoglycans (CSPGs) and nogo-A (Morishita and Hensch, 2008). Nogo-66 receptor $1(\mathrm{NgR} 1)$ is a neuronal receptor for these inhibitors (McGee and Strittmatter, 2003; Dickendesher et al., 2012), and mice lacking the functional gene for $\mathrm{NgR} 1$ retain developmental visual plasticity in adulthood. OD plasticity during the critical period (P19-32) is normal in mice lacking NgR1, but the critical period remains open as this plasticity persists in adult NgR1 mutant mice (McGee et al., 2005). Here we exploit this phenotype of $\mathrm{NgR} 1$ mutant mice to investigate the relationship between OD plasticity and visual acuity.

\section{Materials and Methods}

All procedures and care were performed in accordance with guidelines of the Institutional Animal Care and Use Committee at Children's Hospital Los Angeles.

Mice. The constitutive NgR1 mutant $\left(\mathrm{NgR}^{-/-}\right)$and the conditional $\mathrm{NgR} 1$ mutant $\left(\mathrm{NgR} 1^{\mathrm{flx} / \mathrm{flx}}\right.$ ) were generous gifts of Dr. Stephen Strittmatter, Yale University School of Medicine (Kim et al., 2004; Wang et al., 2011). Both strains had been repeatedly backcrossed onto the C57BL6 background. The $\mathrm{NgR}^{-1-}$ strain was F8 and the $\mathrm{NgR} 1^{\mathrm{flx} / \mathrm{flx}}$ was at least F6 when these mice were re-derived (The Jackson Laboratory). Subsequently, the $\mathrm{NgR} 1^{\mathrm{flx} / \mathrm{flx}}$ was backcrossed onto the C57BL6 background to F8. The Dlx-Cre and PV-Cre driver strains were obtained from The Jackson Laboratory (strain numbers 008199 and 008069, respectively). Genotyping was performed using custom primer sets for PCR amplification. Experiments were performed on both male and female mice.

$M D$. One eye was closed for $4-5 \mathrm{~d}$ for single-unit recording ( $4 \mathrm{~d} \mathrm{MD}$ ) or 3 weeks (P24-P45) for all but one cohort of WT mice at P67-P90 (LTMD) for measurements of visual acuity, using a single mattress suture tied with 6-0 polypropylene monofilament (Prolene 8709H; Ethicon) under brief $1 \%$ isoflurane anesthesia. The knot was sealed with cyanoacrylate glue. At the conclusion of LTMD, mice were briefly anesthetized with isoflurane and the sutures cut away with fine iridectomy scissors. The eyelids were separated and the eye flushed with sterile saline solution. The eye was examined under a stereomicroscope and mice with scarring of the cornea were eliminated from the study.

Visual water task. Visual acuity was estimated with the visual water task (Prusky et al., 2000; Prusky and Douglas, 2003). In brief, two monitors were positioned at the wide end of a trapezoidal tank behind clear Plexiglas. One monitor displayed a sinusoidal spatial frequency grating at $95 \%$ contrast, while the other displayed an isoluminant gray screen. The luminance of the two monitors was matched and gamma corrected with computer software (Eye-One Match 3). Inside the tank, the monitors were separated by a $46 \mathrm{~cm}$ divider. The spatial frequency grating was determined relative to the length of this divider. The tank was filled with water and a hidden platform submerged below the surface of the water in front of the monitor displaying the grating.

Mice were trained to swim toward the monitor displaying the grating and hidden platform after a molding phase during which mice gradually learned to swim from a release chute at the back of the tank toward the monitors. Using a low spatial frequency $(0.1 \mathrm{cpd})$, mice were trained to swim to the monitor presenting the grating. During the training phase, when a mouse chose incorrectly, it repeated the trial on the same side until it chose correctly and was then returned to its home cage. For both the training and the subsequent testing phase, mice swam blocks of 10 interleaved trials in groups of five for a maximum of 4 blocks of trials per day.

During the testing phase, the spatial frequency was increased in small, sequential increments until an animal consistently fell to $70 \%$ accuracy. Starting at $0.1 \mathrm{cpd}$, mice had to succeed at three consecutive trials before proceeding to the next special frequency, which presented one more complete cycle of the sinusoidal grating. Following the first failure, mice were required to achieve five correct trials in a row, or 8 of 10 correct trials at each spatial frequency before proceeding to the next higher frequency. Once a mouse failed to complete 8 of 10 correct trials at a given spatial frequency, it was briefly retrained at half that spatial frequency to eliminate any potential "side bias." Then, testing resumed at the spatial frequency below the original failure. The threshold for visual acuity was established once a mouse exhibited a consistent pattern of performance. Acuity thresholds were estimated as the spatial frequency average from three or more failures at adjacent spatial frequencies. Throughout the testing phase, any mouse that failed to find the hidden platform on the first try repeated the trial one more time before it was returned to its home cage, whether or not it chose correctly the second time.

It has been previously shown that $\mathrm{NgR} 1^{-1-}$ mutant mice exhibit a mild but reproducible deficit in motor coordination on the rotarod (Kim et al., 2004; Lee et al., 2004). However, this motor coordination phenotype does not appear to affect their performance in the visual water task, as both the constitutive NgR1 mutant and conditional NgR1 mutants display performance indistinguishable from WT mice during training and testing.

Statistical analyses for the visual water task dataset were performed with the Kruskal-Wallis test and Dunn's multiple comparison tests or the Mann-Whitney test, as indicated.

Single-unit recording electrophysiology. Recordings were adapted from our previously published methods and were performed by an investigator unaware of the genotype (McGee et al., 2005). Recordings were performed with Epoxylite-coated tungsten microelectrodes with tip resistances of 5-10 M $\Omega$ (FHC), amplifier (model 3600; A-M Systems), and digitizer (micro1401; Cambridge Electronic Design) under Nembutal (50 mg/kg, i.p.; Abbott)/chlorprothixene (10 mg/kg, i.m.; Sigma) anesthesia. Atropine ( $20 \mathrm{mg} / \mathrm{kg}$, s.c.; Sigma-Aldrich) was injected to reduce secretions and the parasympathetic effects of anesthetic agents, and dexamethasone (4 mg/kg, s.c.; American Reagent) was administered to reduce cerebral edema. The mouse was placed in a stereotaxic device after a tracheal tube was inserted. Pure $\mathrm{O}_{2}$ gas was blown over the open aperture of the cannula at $1 \mathrm{~L} / \mathrm{min}$. A craniotomy was made over the left visual cortex, and agar was applied to enhance recording stability and prevent desiccation. The eyelids were removed from both eyes and the corneas protected thereafter by frequent application of silicon oil. Animal temperature was maintained at $37^{\circ} \mathrm{C}$ by a homeostatically controlled heating pad. Heart rate and oxygen saturation were monitored continuously (Kent Scientific).

The electrophysiological responses for four to six cells separated by $>90 \mu \mathrm{m}$ in depth were recorded for each electrode penetration. In each mouse, four to six separate penetrations were spaced evenly at least 200 $\mu \mathrm{m}$ apart across the binocular region, defined by a receptive field azimuth of $<25$ degrees. Responses were evoked with 0.1 cpd $95 \%$ contrast sinusoidal drifting gratings presented at six different orientations separated by $30^{\circ}$ by custom software (MATLAB). Gratings were presented for $2 \mathrm{~s}$ during a $4 \mathrm{~s}$ trial. A blank trial was also included during which no grating was presented. Each of these seven stimuli (six orientations and the blank) was presented six times in random order save that each orientation followed the blank stimuli only once. Action potentials (APs) were identified in recorded traces of neural activity with Spike2 (Cambridge Electronic Design). For each unit, APs were summed for each orientation. The orientation with the greatest number of APs was considered the preferred orientation for analysis. Cells in which the number of APs at the preferred orientation were not at least $50 \%$ greater than the blank were deemed nonresponsive and discarded.

Cells were assigned to OD categories according to the seven category scheme of Hubel and Wiesel (Wiesel and Hubel, 1963). To categorize each unit, first the number of APs for the stimulus blank was subtracted from the number of APs to preferred orientation for stimuli provided to each eye. Next, the responses to the contralateral eye (CE) and ipsilateral eye (IE) were computed as follows: (IE - CE)/(IE + CE) as described previously (Rittenhouse et al., 1999). This scalar was then binned into OD categories $1-7$ as follows: -1 to $-0.75=1,-0.75$ to $-0.45=2$, -0.45 to $-0.15=3,-0.15$ to $0.15=4,0.15$ to $0.45=5,0.45$ to $0.75=$ 6 , and 0.75 to $1=7$. To determine the contralateral bias index $(\mathrm{CBI})$, the 
number of units in each category was summed for all mice in a group, and the CBI calculated according to the following formula: $\mathrm{CBI}=\left[\left(n_{1}-\right.\right.$ $\left.\left.n_{7}\right)+(2 / 3)\left(n_{2}-n_{6}\right)+(1 / 3)\left(n_{3}-n_{5}\right)+N\right] / 2 N$, where $N$ is the total number of units and $n_{x}=$ number of units with OD scores equal to $x$ (Gordon and Stryker, 1996). All comparisons were performed with the Kruskal-Wallis test and Dunn's multiple-comparison correction.

Immunohistochemistry. Mice were deeply anesthetized with ketamine $\mathrm{HCl}$ (200 mg/kg; Phoenix Pharmaceuticals)/xylazine (20 mg/kg; Lloyd Laboratories) and transcardially perfused with PBS (ChemCruz SC-362299) followed by a buffered 4\% PFA/PBS (Acros Organics 416780030). Brains postfixed overnight in $4 \%$ PFA/PBS. Free-floating $40 \mu \mathrm{m}$ sections were cut on a vibrating microtome (Leica VT 1000S) and preserved in PBS containing $0.05 \%$ sodium azide (Sigma-Aldrich S8032).

Coronal sections containing visual cortex were washed in TBS $(50 \mathrm{~mm}$ Tris- $\mathrm{HCl}, 150 \mathrm{~mm} \mathrm{NaCl}, \mathrm{pH} 7.4,3 \times 5 \mathrm{~min}$ ) and then incubated in 100 mm sodium citrate buffer, $\mathrm{pH} 4.5$, (Sigma-Aldrich S1804) at $95^{\circ} \mathrm{C}$ for 10 $\mathrm{min}$ for antigen retrieval. Sections were allowed to cool to room temperature and then washed in TBS $(3 \times 10 \mathrm{~min})$. Sections were incubated in blocking solution of $3 \%$ normal horse serum (Vector Laboratories S-2000) in TBS containing 0.1\% Triton X-100 (TBS-T; Sigma-Aldrich $\mathrm{T} 9284)$ for $1 \mathrm{~h}$ at room temperature. The primary antibodies goat antiNogo Receptor (R\&D Systems; AF1440), mouse anti-PV (Sigma; P3088), and sheep anti- PV (R\&D Systems; AF5058) were diluted in blocking solution to $1 \mu \mathrm{g} / \mathrm{ml}$. In sections double labeled for perineuronal nets, primary antibody was diluted together with fluorescein-conjugated wisteria floribunda agglutinin (WFA; Vector Laboratories; FL-1351) at 2 $\mu \mathrm{g} / \mathrm{ml}$. Sections incubated in primary antibody overnight at $4^{\circ} \mathrm{C}$. After repeated washing in TBS-T $(3 \times 10 \mathrm{~min})$, sections were incubated in Alexa 488- or 594-conjugated secondary antibodies (Jackson ImmunoResearch; 1:200 in blocking solution) for $1 \mathrm{~h}$ at room temperature. After a final series of washes, sections were mounted onto SuperFrost Plus slides (Fisher) with Fluoromount G containing DAPI (Electron Microscopy Science).

Analysis of $P V$ cell and perineuronal net density. Images from coronal sections stained with anti-PV/Alexa 594 and fluorescein-WFA were captured with a BX-51 microscope, $20 \times 0.4 \mathrm{NA}$ objective and 12-bit monochrome camera (Retiga EX; QImaging). DAPI staining was used to demarcate visual cortex before capturing images of PV/WFA density. Two images were required to span the distance from the subcortical white matter to the pial surface. Images were merged in Photoshop following linear contrast adjustment. Data points are the average of at least three sections from each of three animals for each genotype. Statistical comparisons were performed with Student's two-tailed $t$ test.

Patch-clamp electrophysiology and laser scanning photostimulation for circuit mapping. Electrophysiology recording and laser scanning photostimulation (LSPS) mapping experiments were performed on P30-P38 mice. Mice were deeply anesthetized by isoflurane and quickly decapitated. The visual cortex was sectioned into $350 \mu \mathrm{m}$ coronal slices using a vibratome (VT1200S; Leica Systems) in ice-cold artificial CSF (ACSF) containing the following (in mM): $126 \mathrm{NaCl}, 2.5 \mathrm{KCl}, 26 \mathrm{NaHCO}_{3}, 2$ $\mathrm{CaCl}_{2}, 2 \mathrm{MgCl}_{2}, 1.25 \mathrm{NaH}_{2} \mathrm{PO}_{4}$, and 10 glucose. The slices were then incubated in ACSF saturated with 95 and $5 \% \mathrm{CO}_{2}$ for $30 \mathrm{~min}$ at $32^{\circ} \mathrm{C}$, and switched to room temperature in the same ACSF for at least $30 \mathrm{~min}$ before transferring to the recording chamber.

Slices were visualized with a microscope (BX51WI; Olympus) equipped with infrared DIC optics and an epifluorescent light source. V1 binocular zone was identified based on the coordinates as well as laminar and cytoarchitectonic features (Xu and Callaway, 2009) and electrophysiological recordings were performed as described previously (Qiu et al., 2011). Slices were visualized either with a low-magnification objective (4×, NA 0.13; Olympus; for LSPS mapping) or high-magnification objective $(60 \times$ water-immersion LUMPlanFl, NA 0.9; Olympus; for targeted patching). Digital slice images were acquired with a charge-coupled digital camera (Retiga 2000DC; QImaging), and were used for registering photostimulation locations. The td-Tomato ${ }^{+} \mathrm{PV}$ neurons in binocular zone were identified under DIC and epifluorescence for patch-clamp whole-cell recording. Series resistance $\left(R_{s}\right)$ was monitored throughout recordings; only stable ( $<15 \%$ change) cells with $R_{\mathrm{s}}<30 \mathrm{M} \Omega$ throughout the recordings were included. Intrinsic properties were measured in current-clamp mode immediately by injecting current steps $(1 \mathrm{~s}$ duration, -100 to $+500 \mathrm{pA}$ in $50 \mathrm{pA}$ increments). Passive membrane properties were calculated based on current responses to a negative voltage command pulse. Traces were analyzed off-line to identify APs and to calculate the current injection-firing frequency relationships. Electrophysiological signals were amplified with a Multiclamp 700B amplifier (Molecular Devices) and acquired with BNC 6259 data acquisition boards (National Instruments) and the Ephus software (Ephus available at https://openwiki.janelia.org/). Signals were digitized and acquired at $10 \mathrm{kHz}$. The patch electrode was pulled from borosilicate glass and had electrical resistance of 4-6 M $\Omega$. For LSPS mapping experiments, the electrode internal solution contains the following (in $\mathrm{mm}$ ): 130 K-gluconate, $4 \mathrm{KCl}, 2 \mathrm{NaCl}, 10 \mathrm{HEPES}, 4 \mathrm{ATP}-\mathrm{Mg}, 0.3 \mathrm{GTP}-\mathrm{Na}$, and 14 phosphocreatine, $\mathrm{pH} 7.2,295 \mathrm{mOsm}$.

LSPS mapping on slices was performed in a perfusion chamber mounted on a motorized stage (Sutter Instruments) at room temperature. The chamber was perfused with modified ACSF with higher concentrations of magnesium and calcium containing the following (in $\mathrm{mm}$ ): $126 \mathrm{NaCl}, 2.5 \mathrm{KCl}, 26 \mathrm{NaHCO}_{3}, 4 \mathrm{CaCl}_{2}, 4 \mathrm{MgCl}_{2}, 1.25 \mathrm{NaH}_{2} \mathrm{PO}_{4}$, and 10 glucose at $1.5-2 \mathrm{ml} / \mathrm{min}$ (Qiu et al., 2011). This modified ACSF also contains $5 \mu \mathrm{M}$ R-CPP (Tocris Bioscience; to block NMDA receptor currents and plasticity) and $0.2 \mathrm{~mm}$ MNI-caged glutamate (Tocris Bioscience). Neuronal cell bodies were at least $50 \mu \mathrm{m}$ below the surface of the slice. LSPS was performed through a $4 \times$ objective lens (NA 0.13; Olympus) and $20 \mathrm{~mW}, 1 \mathrm{~ms}$ UV laser ( $355 \mathrm{~nm}$; DPSS Lasers) pulses were scanned onto the sample after passing an electro-optical modulator (Conoptics) and a mechanical shutter (Uniblitz). We have empirically determined that LSPS-evoked APs can only be recorded from stimulation locations within $100 \mu \mathrm{m}$ of the soma, suggesting that stimulation is rather focal. For LSPS mapping experiments, synaptic currents in patched neurons were detected under voltage clamp. A stimulus grid $(16 \times 16,75 \mu \mathrm{m}$ spacing) was overlaid on the binocular $\mathrm{V} 1$ region, spanning from pia to white matter. For each L2/3 PV neuron, the grid was centered horizontally over the soma, and aligned at the top edge with the pia. PV neurons were voltage clamped at $-70 \mathrm{mV}$ (calculated reversal potential for chloride ions) during the LSPS mapping to minimize the contamination of chloride currents. In some experiments where excitation profiles were calculated for L4 neurons (Shepherd and Svoboda, 2005; Weiler et al., 2008; Qiu et al., 2011), loose-seal recordings were made from these neurons with the amplifier in current-clamp mode. The spike-generating sites of neurons were mapped using an $8 \times 8$ stimulus grid with $50 \mu \mathrm{m}$ spacing. This approach was also used to estimate the resolution and intensity of stimulation, and intrinsic excitability of L4 neurons.

To measure sEPSCs in L2/3 PV + neurons and pyramidal neurons, a whole-cell recording was obtained in these neurons (voltage clamped at $-70 \mathrm{mV}$ ) using the same electrode internal solution as LSPS experiments. In experiments where sIPSCs were measured in L2/3 pyramidal neurons, an internal solution with symmetrical chloride concentration was used. This internal solution contains the following (in mM): $135 \mathrm{KCl}$, $2 \mathrm{NaCl}, 10 \mathrm{HEPES}, 2$ EGTA, 5 QX314-Cl, $1 \mathrm{MgSO}_{4}$, 4 ATP-Mg, and 0.3 GTP-Tris, pH 7.4, with $\mathrm{KOH}, 290-295$ mOsm. The ACSF was also supplemented with NBQX and $50 \mu \mathrm{M}$ AP5.

\section{Results}

$\mathrm{NgR} 1^{-/-}$mice display extended plasticity in visual cortex and improved visual acuity following LTMD

First, we confirmed that $\mathrm{NgR} 1$ mutant $\left(\mathrm{NgR} 1^{-/-}\right)$mice display developmental OD plasticity in adulthood when WT mice do not. In WT mice, $4 \mathrm{~d}$ of MD initiated during the critical period (P26-P28), but not thereafter (P60), shifts the binocularity of neurons in primary visual cortex toward the nondeprived eye, as measured by single-unit recordings under barbiturate anesthesia (Gordon and Stryker, 1996). In contrast, P60 NgR1 ${ }^{-/-}$mice exhibit OD plasticity indistinguishable from that obtained in WT mice during the critical period (P19-P32). This plasticity results in a rightward shift toward the nondeprived eye in OD histograms (Fig. 1A), lower scores for CBI (Fig. $1 B$; WT vs WT CP $4 \mathrm{~d}$ 
$\mathrm{MD}, p=0.018$; WT vs $\mathrm{NgR} 1^{-/-} 4 \mathrm{~d} \mathrm{MD}$, $p=0.023)$, and a rightward shift in the cumulative distribution of OD scores for individual units (Fig. $1 C$; WT vs WT CP $4 \mathrm{~d}$ MD $p<0.0001$; WT vs $\mathrm{NgR}^{-1-} 4 \mathrm{~d}$ $\mathrm{MD}, p<0.0001$, Kolmogorov-Smirnov test of cumulative distribution).

Next, to evaluate the potential role for NgR1 in limiting recovery from prolonged $\mathrm{MD}$, we began by comparing the maturation of visual acuity in WT and $\mathrm{NgR}^{-/-}$mice with a behavioral assay, the visual water task (Prusky et al., 2000). We used this behavioral assay because it is a direct measure of visual function. We tracked acuity in juvenile WT mice every $5 \mathrm{~d}$ from P25 to P45. Visual acuity was modest at P25 and improved over 2 weeks to plateau near P40 (Fig. 1D). Thus, we observe that visual acuity improves gradually, reaching adult levels with the close of the critical period. Maturation of acuity is identical in $\mathrm{WT}$ and $\mathrm{NgR} 1^{-/-}$mice (Fig. 1D).

To determine whether persistent OD plasticity is associated with an improvement in acuity following abnormal visual experience, we measured visual acuity of the deprived eye in $\mathrm{WT}$ and $\mathrm{NgR} 1^{-1-}$ mice following LTMD (P25-P45; Fig. 1E). This deprivation extended 2 weeks beyond the close of the critical period $(\sim$ P32). Seven days after restoring vision following LTMD, WT mice displayed lower acuity through the deprived eye (Fig. $1 E, F)$. This deficit is permanent; visual acuity 7 weeks after reopening the deprived eye (WT, $0.31 \pm 0.03 \mathrm{cpd}$; Fig. $1 F$ ) is similar both to acuity measured near the age of deprivation (P24; WT P25, $0.24 \pm$ $0.04 \mathrm{cpd}$; Fig. $1 D$ ) and $7 \mathrm{~d}$ after reopening the deprived eye (WT, $0.25 \pm 0.04 \mathrm{cpd}$; Fig. $1 F$ ). This same duration of LTMD initiated after the close of the critical period does not affect acuity (Prusky and Douglas, 2003). WT mice and NgR1 ${ }^{-1-}$ mice display similar sensitivity to LTMD during the critical period as visual acuity of the deprived eye during the first week after restoring vision is nearly identical between $\mathrm{NgR} 1^{-1-}$ and WT mice $(\sim \mathrm{P} 50$; Fig. $1 E, F ; 7 \mathrm{~d}$ post-LTMD WT vs NgR $1^{-1-}, p=0.92$, Mann-Whitney test). However, visual acuity of the deprived eye improves gradually in $\mathrm{NgR} 1^{-/-}$mice after restoring vision. Seven weeks later, the acuity by the previously deprived eye is significantly greater in $\mathrm{NgR}^{-/-}$mice (Fig. $1 F$ ). Interestingly, acuity through the previously deprived eye in $\mathrm{NgR}^{-/-}$mice is indistinguishable from that of normal (naive) mice through one eye (Fig. $1 F ; 7$ weeks post-LTMD WT vs NgR1 ${ }^{-1-}, p=0.004$; $\mathrm{NgR} 1^{-1-}$ normal vs 7 weeks post-LTMD, $p>0.9$, Mann-Whitney test).

B

D
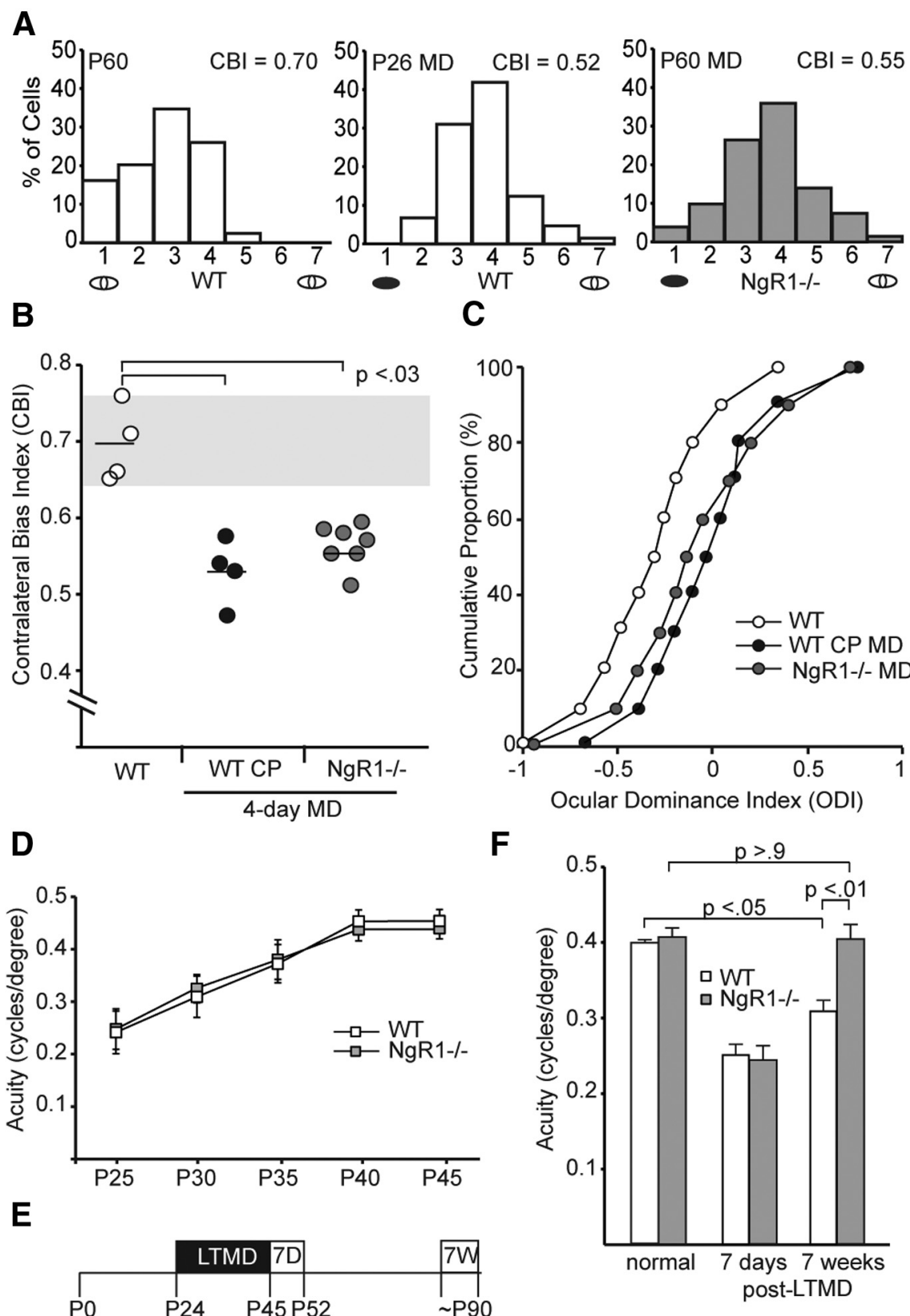

Figure 1. NgR1 mutant mice are sensitive to MD beyond the critical period and display improved visual acuity following LTMD $A, 0 D$ histogram and CBI score for nondeprived WT mice after the critical period at P60 (111 units, 4 mice) as well as WT during the critical period (P26; 65 units, 4 mice) and P60 NgR1 ${ }^{-1-}$ mice (NgR1 ${ }^{-1-} ; 173$ units, 7 mice) after $4 \mathrm{~d} \mathrm{MD}$. MD is indicated with a black ellipse beneath the histogram. $\boldsymbol{B}$, CBI scores for individual mice across age, genotype, and condition. Groups receiving MD are underlined. The gray box indicates the typical range of $\mathrm{CB}$ v values for nondeprived mice. Black lines represent the average $\mathrm{CBI}$ score for each group. Statistical significance $p<0.03$ between WT versus WT CP and NgR1 ${ }^{-1-}$ ( $n=$ number of mice per group above). C, Cumulative histograms of ODI scores for groups reported in A. D, Acuity measured through both eyes every $5 \mathrm{~d}$ from P25 to P45 with the visual water task ( $n=8$ mice per genotype). Error bars indicate SEM. $E$, A schematic of the schedule for LTMD and acuity testing. Following 3 weeks of LTMD, mice were tested either $7 \mathrm{~d}$ or 7 weeks after eye re-opening. $F, \mathrm{NgR}^{-1-}$ mice display greater visual acuity than WT mice 7 weeks after LTMD ( $p<0.01$; normal, WT $n=4, \mathrm{NgR}^{-1-} n=4 ; 7$ week LTMD, WT $n=8$, $\mathrm{NgR} 1^{-1-}, n=10$ ). Bars represent average acuity by one eye for naive mice and the previously deprived eye for mice receiving LTMD. Error bars represent SEM. Statistical analyses were performed with the Kruskal-Wallis test and Dunn's multiple-comparison test where multiple pairwise comparisons are presented.

Restricting deletion of $\mathrm{NgR} 1$ to cortical inhibitory neurons extends developmental OD plasticity but does not improve acuity following LTMD

$\mathrm{NgR} 1$ is expressed by cortical neurons, as well as within the lateral geniculate nucleus of the thalamus (Barrette et al., 2007). To dissect where within the circuitry of the visual system NgR1 ex- 
A

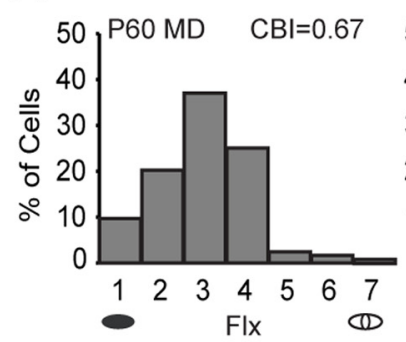

B
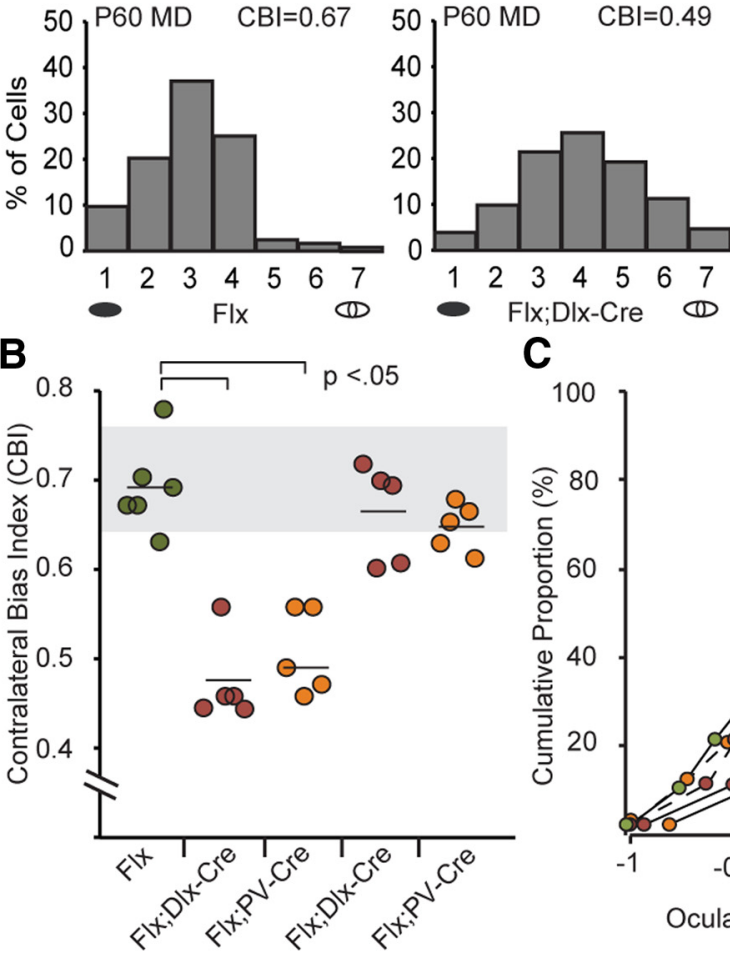

C
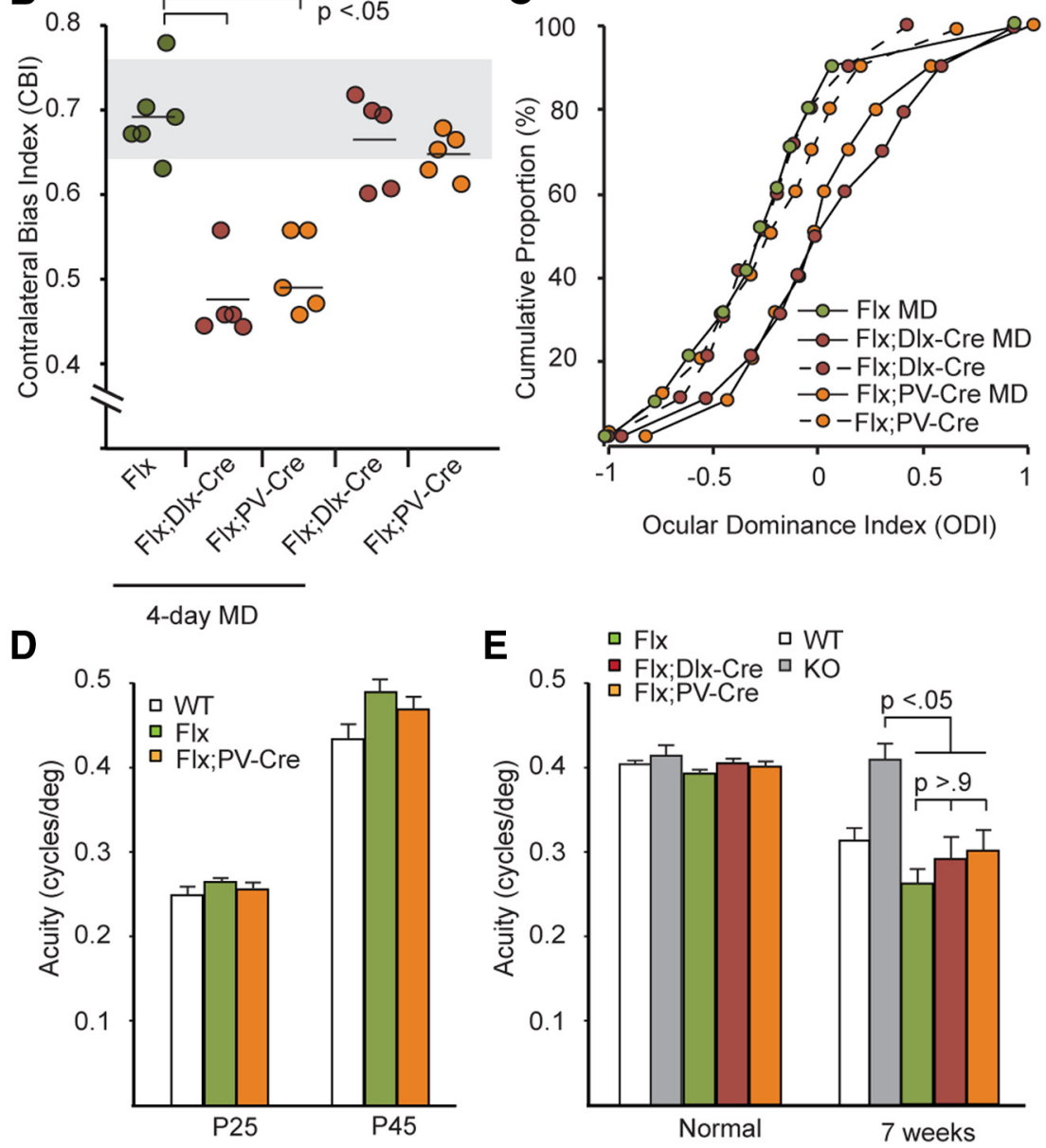

E
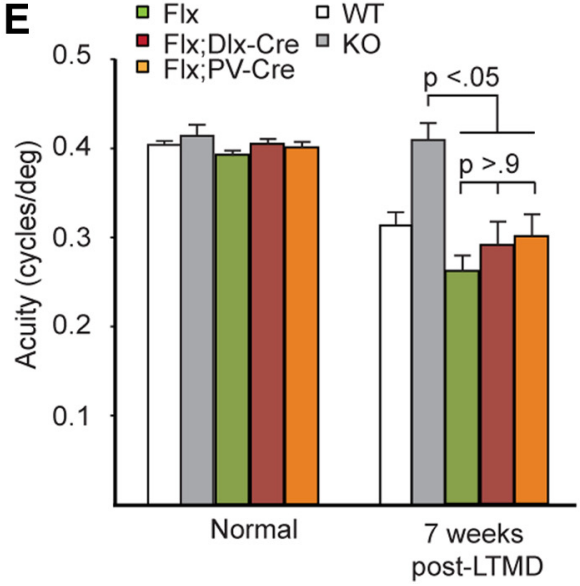

Figure 2. Restricting deletion of $\mathrm{NgR} 1 \mathrm{t}$ to cortical inhibitory neurons permits $0 \mathrm{D}$ plasticity but not improvement of acuity. $A, 0 \mathrm{D}$

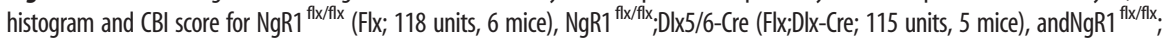
PV-Cre (Flx;PV-Cre; 109 units, 5 mice) following $4 \mathrm{~d} \mathrm{MD}$ at P60. B, CBI scores for individual mice across age, genotype, and condition. Groups receiving $4 \mathrm{dMD}$ are underlined. This also includes two groups for which $0 \mathrm{D}$ histograms are not presented in $A$ : nondeprived Flx;Dlx-Cre mice (103 units, 5 mice) and nondeprived Flx;PV-Cre (113 units, 5 mice) mice at P60. The gray box indicates the typical range of $\mathrm{CBI}$ values for nondeprived mice. Flx;Dlx5/6-Cre and Flx;PV-Cre mice display OD plasticity indistinguishable from $\mathrm{NgR1}{ }^{-1-}$ mice (Fig. 1B). Black lines represent the average $\mathrm{CBI}$ score for each group. C, Cumulative histograms of ODI scores for Flx MD, Flx;Dlx-Cre MD, Flx;PV-Cre MD, Flx;Dlx-Cre, and Flx;PV-Cre. D, Acuity of naive mice measured through both eyes of WT (P25, $n=8 ; P 45, n=3)$, Flx (P25, $n=7 ; P 45, n=3)$, and Flx;PV-Cre mice $(P 25, n=6 ; P 45, n=4)$. E, Acuity of naive mice measured through one eye for Flx $(n=5)$, Flx;Dlx-Cre $(n=3)$, and Flx;PV-Cre mice $(n=5)$. Acuity 7 weeks after LTMD measured through the previously deprived eye for Flx $(n=17)$, Flx;Dlx-Cre $(n=12)$, and Flx;PV-Cre mice $(n=5)$. The acuity of Flx, Flx;Dlx-Cre, and Flx;PV-Cre mice following LTMD is significantly lower than $\mathrm{NgR} 1^{-1-}$ mice ( $p<0.05$ for each comparison). Statistical comparisons were performed with the Kruskal-Wallis test and Dunn's multiple-comparison correction.

pression is required to restrict OD plasticity and limit improvement of visual acuity following abnormal vision, we examined mice harboring a conditional NgR1 allele, $\mathrm{NgR} 1^{\text {flx/flx }}$ (Wang et al., 2011). In this allele, loxP sites flank the second exon of NgR1. This exon contains the entire amino acid sequence of the mature receptor. Cre recombinase excises this second exon and abolishes expression of NgR1 (Wang et al., 2011).

Given the prominent role of inhibitory circuitry in regulating the critical period for OD plasticity (Levelt and Hübener, 2012), we tested the hypothesis that abolishing NgR1 expression selectively in interneurons would also prevent closing of the critical period and thereby permit OD plasticity in adult mice similar to the $\mathrm{NgR} 1^{-/-}$constitutive mutant. First, we directed deletion of NgR1 to cortical inhibitory neurons with the Cre driver Dlx5/6-Cre. The Dlx5/6-Cre transgene confines Cre recombinase expression to differentiating and migrating forebrain interneurons as early as E13.5 (Stühmer et al., 2002; Monory et al., 2006). We found that similar to WT mice, $4-5 \mathrm{~d}$ of $\mathrm{MD}$ initiated at P60 does not affect OD in $\mathrm{NgR} 1^{\mathrm{flx} / \mathrm{flx}}$ mice (Fig. $2 A, B$ ). In contrast, $4-5 \mathrm{~d}$ of MD yielded marked OD shifts in NgR $1^{\text {flx/flx }}$;Dlx5/6-Cre mice (Fig. 2B, Flx vs Flx;Dlx-Cre, $p=0.0018$ ) (Fig. $2 A-C$ ). The magnitude of this plasticity following 4-5 d of MD was indistinguishable from either $\mathrm{NgR} 1^{-/-}$mice at $\mathrm{P} 60$ or WT mice during the critical period (P26-P28; Fig. 1). Naive $\mathrm{NgR} 1^{\text {flx/flx }} ; \mathrm{Dlx} 5 / 6$-Cre mice exhibit normal ocular dominance (Fig. $2 B, C)$. Thus, eliminating NgR1 expression only in cortical inhibitory neurons is sufficient to maintain OD plasticity in adult mice.

Next, we tested whether restricting NgR1 deletion to the PV-positive subpopulation of inhibitory neurons was sufficient to retain OD plasticity in the adult. In visual cortex, PV is expressed in an abundant population of fast-spiking inhibitory basket cells (Kawaguchi and Kubota, 1993); 50\% of GABAergic interneurons in visual cortex express PV (Gonchar and Burkhalter, 1997). Notably, the number of PV neurons in visual cortex plateaus during the critical period (Huang et al., 1999) while an increase in the distribution of perineuronal nets that encapsulate the soma of PV neurons coincides with the close of the critical period (Pizzorusso et al., 2002). Perineuronal nets are enriched with CSPGs, ligands for NgR1 (Dickendesher et al., 2012). We deleted NgR1 with PV-Cre, a "knock-in" Cre driver (Hippenmeyer et al., 2005). $\mathrm{NgR} 1^{\text {flx/flx }}$;PV-Cre mice also display OD plasticity at P60 (Fig. 2B, Flx vs Flx;DlxCre, $p=0.046)($ Fig. $2 A-C)$. Thus, both adult NgR1 ${ }^{\text {flx } / f l x} ; \mathrm{Dlx} 5 / 6-$ Cre and $N g R 1^{\text {flx/flx }}$;PV-Cre mice exhibit developmental OD plasticity similar to WT mice during the critical period as revealed by rightward shifts in OD histograms (Fig. 2A), lower CBI scores (Fig. $2 B$ ), and a rightward shift in the cumulative distribution of 
A

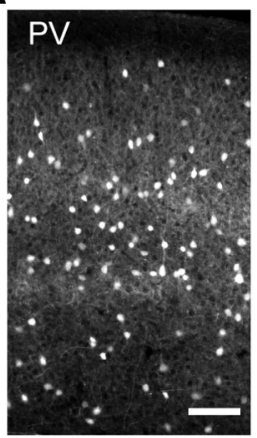

B

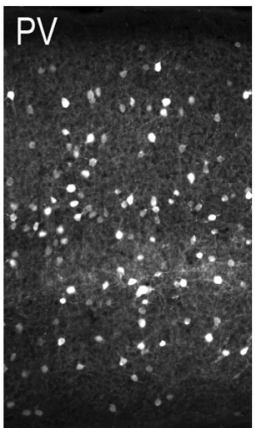

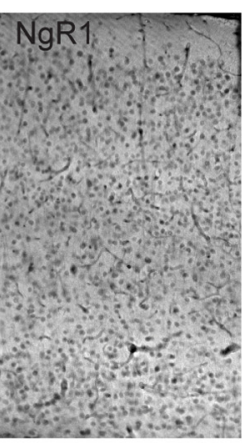

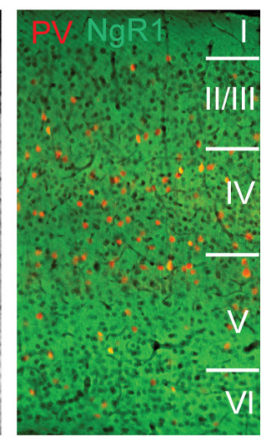

C

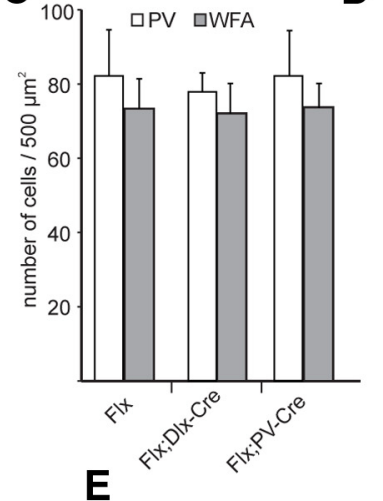

E
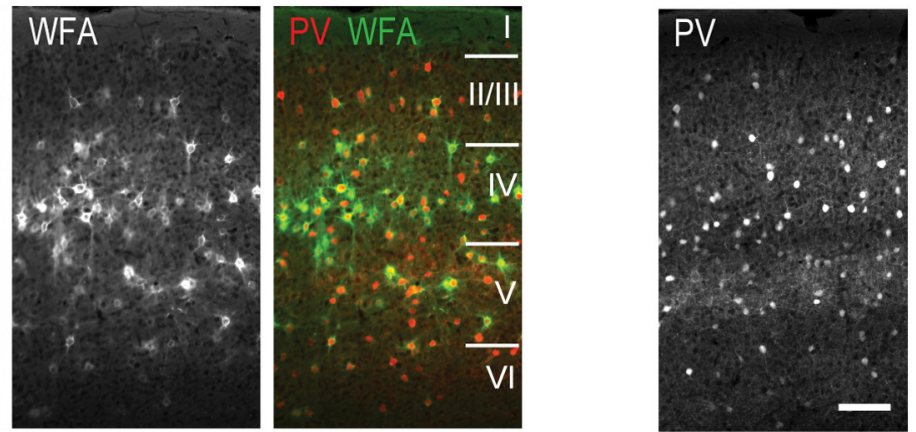
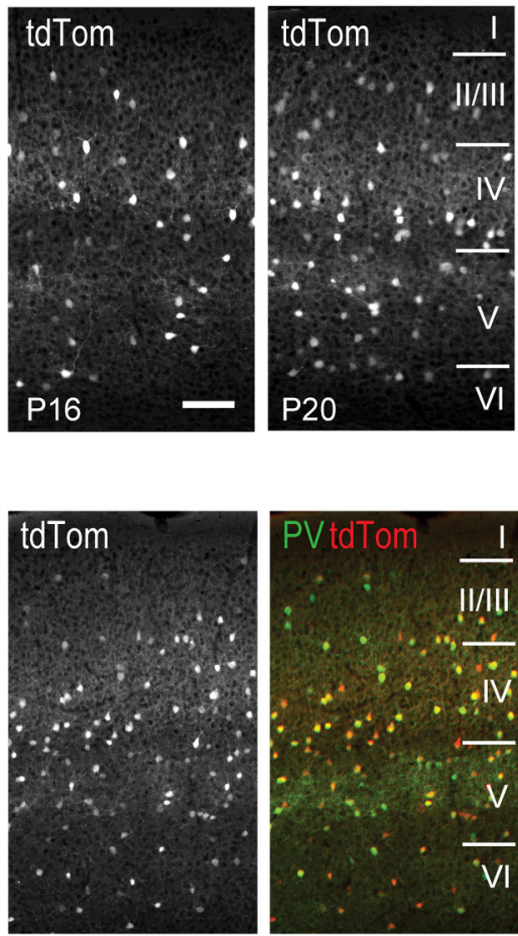

Figure 3. Deleting NgR1 in PV interneurons does not alter their distribution or development. $A$, Immunostaining of visual cortex for PV (red in overlay) and nogo receptor (NgR1; green in overlay). $\mathrm{NgR1}$ expression is extensive throughout the neuropil. $\boldsymbol{B}$, Immunostaining for PV (red in overlay) and perineuronal nets with WFA (green in overlay) in visual cortex of an NgR1 ${ }^{\mathrm{fl} / f \mathrm{fl}}$ mouse. $\boldsymbol{C}$,

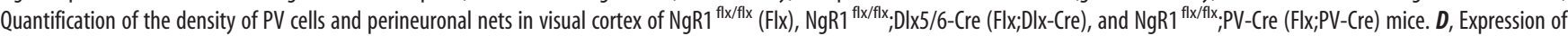
Td-tomato (tdTom) following (re recombination in visual cortex at P16 and P20 during differentiation of PV neurons in visual cortex. $E$, Adult visual cortex immunostained for PV (green in overlay) and expressing Td-tomato (red in overlay) following Cre recombination. The relative positions of layers II/III through VI in cortex are indicated in the color overlay. Scale bar, $100 \mu \mathrm{m}$.

OD index (ODI) values (Fig. 2C). As both Dlx5/6a-Cre and PVCre drive expression of Cre recombinase in cortical PV interneurons, these experiments provide direct evidence that PV neurons contribute to regulating the closure of the critical period for OD plasticity.

Last, to investigate the relationship between OD plasticity and visual acuity, we tested whether deleting NgR1 selectively in inhibitory neurons with Dlx5/6-Cre or PV-Cre is sufficient to improve visual acuity after LTMD, akin to the phenotype of the constitutive NgR1 mutant $\left(\mathrm{NgR} 1^{-/-}\right)$. During the critical period, $\mathrm{NgR} 1^{\text {flx/flx }}$ and $\mathrm{NgR} 1^{\text {flx/flx }}$;PV-Cre mice display visual acuity similar to WT mice (P25; Fig. 2D). Naive $\mathrm{NgR} 1^{\mathrm{flx} / \mathrm{flx}}$ mice, $\mathrm{NgR} 1^{\text {flx/flx }} ; \mathrm{Dlx} 5 / 6$-Cre mice, and NgR $1^{\text {flx/flx }}$;PV-Cre mice also possess normal visual acuity at P45 as acuity plateaus in WT mice (Fig. $2 D, E$ ). However, NgR $1^{\mathrm{flx} / \mathrm{flx}} ; \mathrm{Dlx} 5 / 6$-Cre mice and NgR1 $1^{\mathrm{flx} / \mathrm{fl} x}$; PV-Cre mice also exhibit deficits in visual acuity after LTMD similar to $\mathrm{NgR} 1{ }^{\mathrm{flx} / \mathrm{flx}}$ mice (Fig. $2 E$ ). The resultant visual acuity of these three strains is similar to WT mice and is significantly lower than that of $\mathrm{NgR}^{-/-}$mice $\left(\mathrm{NgR}^{-/-}\right.$vs Flx, $p<0.001$; $\mathrm{NgR}^{-/-}$vs Dlx-Cre, $p=0.015 ; \mathrm{NgR}^{-/-}$vs PV-Cre, $p=0.044$; Fig. 2E). Thus, although NgR1 functions within PV interneurons to restrict OD plasticity beyond the critical period, this plasticity within cortical circuitry is not sufficient to improve visual acuity after prolonged abnormal visual experience during development.

Single-unit recordings in visual cortex largely reflect the activity of the predominant population of excitatory neurons. As deleting NgR1 in either cortical inhibitory neurons, or more selectively in PV interneurons, retains OD plasticity in the adult, loss of NgR1 expression within inhibitory neurons results in plasticity of binocularity by excitatory neurons in visual cortex. NgR1 is expressed by PV interneurons and the number of PV interneurons in visual cortex is normal in $\mathrm{NgR} 1^{-/-}$mice (McGee et al., 2005). Overall, we observe that $\mathrm{NgR} 1$ expression is extensive throughout the cortical neuropil and appears present in both PV and principal neurons across cortical layers (Fig. 3A). However, to determine whether selective deletion of $\mathrm{NgR} 1$ adversely affects the number or function of PV neurons, we counted the number of PV neurons in sections of visual cortex from $\mathrm{NgR} 1^{\text {flx/flx }}, \mathrm{NgR} 1^{\text {flx/flx }} ; \mathrm{Dlx} 5 / 6$ Cre, and NgR $1^{\mathrm{flx} / \mathrm{flx}} ; \mathrm{PV}$-Cre mice labeled with antibodies directed against $\mathrm{PV}$ (Fig. $3 B, C$ ). The number of $\mathrm{PV}$ neurons is unaltered by the expression of Cre recombinase and the deletion of the $\mathrm{NgR} 1$ gene.

In addition, we used a Cre-dependent td-Tomato reporter strain (Ai14) to evaluate the specificity of Cre activity in PV-Cre mice (Madisen et al., 2010). We observe that the onset of Cre recombination mirrors the differentiation of PV neurons during the third week postnatal (Fig. 3D) and that PV-Cre restricts tdTomato expression to cells expressing PV in adult visual cortex (Fig. 3E) consistent with previous studies (Pfeffer et al., 2013). Cortical PV neurons are ensheathed by perineuronal nets containing CSPGs. These components of the extracellular matrix are known to limit visual plasticity (Pizzorusso et al., 2002, 2006; Carulli et al., 2010). We also examined if selective deletion of NgR1 affects the distribution of perineuronal nets by staining sections of visual cortex with the fluorescein-labeled lectin WFA (Fig. 3B). The distribution of WFA-positive perineuronal nets is nearly identical in visual cortex of $\mathrm{NgR} 1^{\mathrm{flx} / \mathrm{flx}}, \mathrm{NgR} 1^{\mathrm{flx} / \mathrm{flx}} ; \mathrm{Dlx} 5 / 6$ Cre, and NgR $1^{\text {flx/flx }}$;PV-Cre mice (Fig. $3 C$ ). 
A
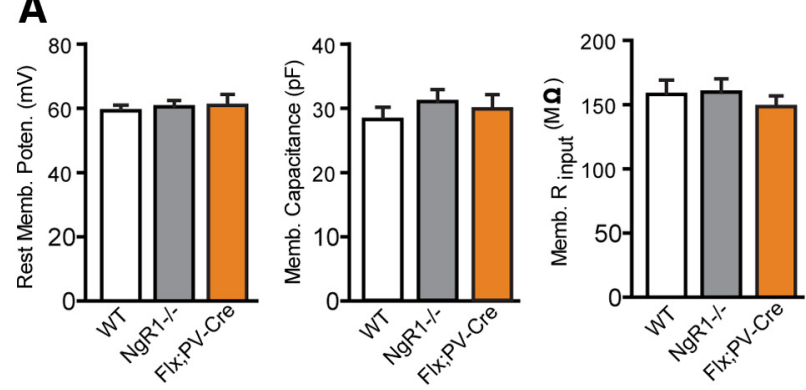

C

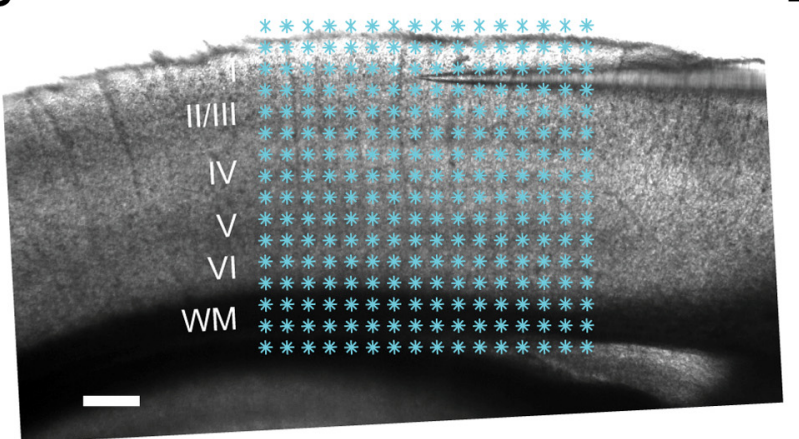

B

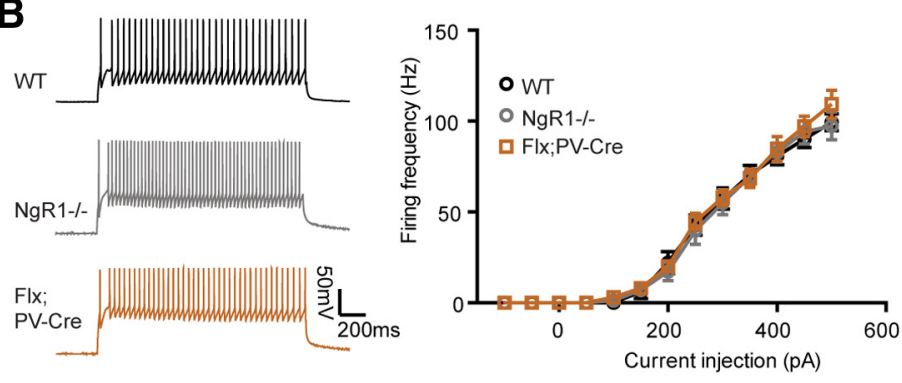

D

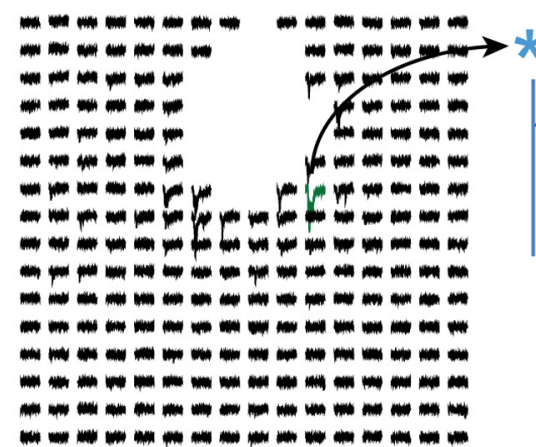

E

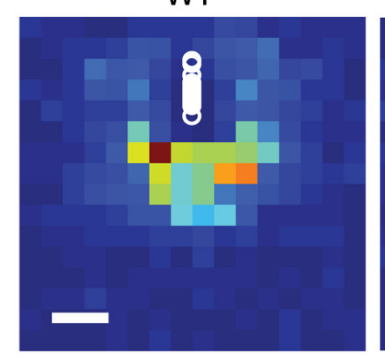

NgR1-/-

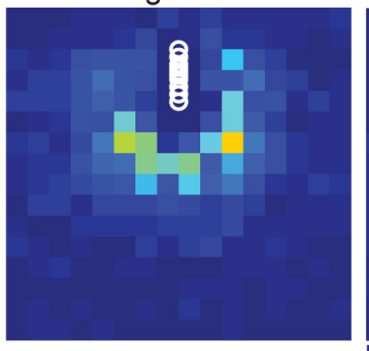

Flx;PV-Cre

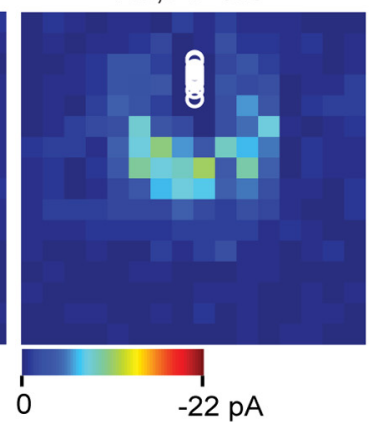

$\mathbf{F}$

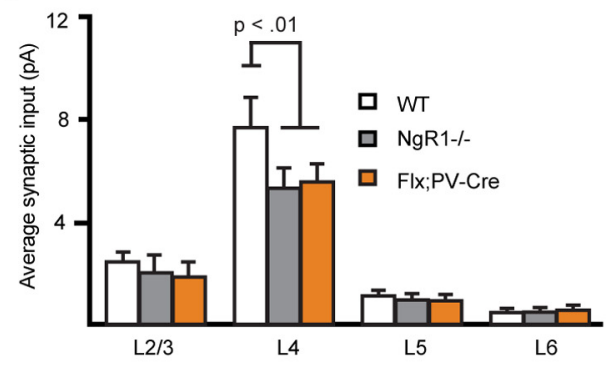

Figure 4. Intrinsic excitability is normal in L2/3 PV neurons in visual cortex of $\mathrm{NgR}^{-1-}$ and $\mathrm{NgR1} \mathrm{fl}^{\text {flfflx }}$;PV-Cre mice, but excitatory synaptic input from $\mathrm{L} 4$ is decreased. $\boldsymbol{A}$, Resting membrane potential, membrane capacitance, and membrane input resistance are similar between $\mathrm{NgR}^{-1-} ; \mathrm{NgR1} 1^{\mathrm{fl} / \mathrm{ffx}} ; \mathrm{PV}$-Cre (Flx; PV-Cre) and WT mice $(p>0.05$ for all three measures, one-way ANOVA). $B$, Frequency of AP firing as a function of current injection is nearly identical between genotypes ( $p=0.42$ for the effect of genotype, two-way ANOVA). C, Example of an L2/3 PV interneuron recorded in binocular V1 in an acute slice; overlaid are $16 \times 16$ LSPS stimulation locations spanning pia to white matter. Scale bar, $200 \mu \mathrm{m}$. D, Representative traces from LSPS-evoked EPSCs measured across $16 \times 16$ locations ( $75 \mu \mathrm{m}$ spacing) from an L2/3 PV interneuron. Direct somatic responses have been removed for clarity. A higher magnification trace of the LSPS position indicated by the arrow is shown at right (green). Blue asterisk denotes laser pulse onset. $\boldsymbol{E}$, In vitro LSPS aggregate excitatory input maps pooled across PV interneurons. Circles indicate soma location (WT, 4 mice, $n=16$ cells; NgR1 ${ }^{-1-}, 4$ mice, $n=9$ cells; Flx;PV-Cre, 4 mice, $n=14$ cells). $\boldsymbol{F}$, Mean LSPS-evoked EPSC amplitude from neurons recorded in $\boldsymbol{E}$ binned into L2/3, L4, L5, and L6. The mean LSPS-evoked amplitudes in $\mathrm{L} 4$ are significantly lower in $\mathrm{NgR}^{-/-}$and Flx;PV-Cre mice than WT mice ( $p<0.01$ for both comparisons; two-way ANOVA with Bonferroni post hoc test).

NgR1 regulates intralaminar connectivity in visual cortex To determine whether complete or restricted deletion of NgR1 perturbs the intrinsic electrophysiologic profile of PV neuron function, we performed whole-cell recordings on acute cortical slices from WT, NgR $1^{-/-}$, and NgR1 ${ }^{\text {flx/flx }}$;PV-Cre mice, which also expressed td-Tomato from the Ail4 reporter. Resting membrane potential, membrane capacitance, and input resistance were nearly identical in PV neurons between these genotypes (Fig. $4 A ; p=0.37$, one-way ANOVA). The firing rate in response to current injection was also indistinguishable between genotypes (Fig. $4 B ; p=0.42$, two-way ANOVA, for the effect of genotype). Therefore, neither complete nor restricted loss of NgR1 yields a detectable difference in the intrinsic electrophysiologic properties of PV interneurons.

Cortical inhibitory neurotransmission by PV neurons contributes to the regulation of the critical period for OD plasticity (Levelt and Hübener, 2012; Kuhlman et al., 2013). Therefore, we investigated if synaptic connectivity onto PV neurons is disrupted by complete or restricted deletion of $\mathrm{NgR} 1$. We mapped the distribution and strength of synaptic inputs onto layer 2/3 PV interneurons (PVCre:Ai14) in the binocular zone of V1 with glutamate uncaging by LSPS (Shepherd et al., 2003; Qiu et al., 2011; Fig. 4C,D). Consistent with preceding reports (Kuhlman et al., 2013), we observed that the strongest cortical synaptic inputs onto L2/3 PV neurons in visual cortex arise from L4 (Fig. $4 E$ ). This major laminar excitatory input from L4 is significantly decreased compared with WT controls for both $\mathrm{NgR} 1^{-l-}$ and $\mathrm{NgR} 1^{\text {flx/flx }}$;PV-Cre mice (Fig. 4E). The average strength of synaptic inputs from L4 in both NgR1 mutants showed a significant reduction compared with WT (Fig. 4F; average L4 input strength, WT $7.7 \pm 1.1 \mathrm{pA} ; \mathrm{NgR}^{-/-}, 5.4 \pm 0.7 \mathrm{pA}$; and NgR1 ${ }^{\text {flx } / \mathrm{flx}}$; PV-Cre, $5.6 \pm 0.6 \mathrm{pA}$; compared with WT, $p<0.01$ for both 
$\mathrm{NgR} 1^{-/-}$and $\mathrm{NgR} 1^{\text {flx/flx }}$;PV-Cre neurons, two-way ANOVA with Bonferroni post hoc test). The decreased synaptic drive from L4 to $\mathrm{L} 2 / 3 \mathrm{PV}$ neurons is not due to diminished overall excitability of L4 neurons because L4 neurons are equally excitable by uncaged glutamate between these three genotypes, as measured by their excitation profiles $(n=$ 5-9, data not shown). Therefore, L2/3 PV neurons receive less synaptic input from L4 as a result of $\mathrm{NgR} 1$ deletion.

Last, to investigate if the decreased synaptic drive from L4 onto L2/3 PV neurons alters inhibitory synaptic connectivity onto L2/3 pyramidal neurons, we measured spontaneous excitatory postsynaptic current (sEPSC) responses in L2/3 PV neurons as well as both sEPSC and spontaneous inhibitory postsynaptic current (sIPSC) responses in $\mathrm{L} 2 / 3$ pyramidal neurons in acute slices of visual cortex obtained from WT, NgR1 ${ }^{-/-}$, and NgR $1^{\text {flx } / f l x} ; \mathrm{PV}$-Cre mice (Fig. 5). These recordings revealed a significant decrease in the frequency of sEPSCs $(n=8$ for each genotype, $p<0.05$, one-way ANOVA with Student-Newman-Keuls post hoc test) but no change in the amplitude $(p>0.05$, Kolmogorov-Smirnov test) on L2/3 PV neurons in both $\mathrm{NgR} 1^{-/-}$and $\mathrm{NgR} 1^{\mathrm{flx} / \mathrm{flx}}$; PV-Cre mice (Fig. 5A-C). This is consistent with the diminished excitatory synaptic drive from L4 we observed with LSPS experiments (Fig. $4 E, F$ ). In similar experiments, we detected a decrease in the frequency ( $n=7$ for each genotype, $p<0.05$, one-way ANOVA) but not amplitude of sIPSCs $(p>0.05$, Kolmogorov-Smirnov test) in L2/3 pyramidal neurons (Fig. 5D-F). In contrast, sEPSCs frequency $(n=6-9, p>$ $0.05)$ and amplitude $(p>0.05$, Kolmogorov-Smirnov test) recorded from L2/3 pyramidal neurons were similar (Fig. 5G-I). Thus, the decreased excitatory synaptic drive onto L2/3 PV interneurons from L4 is accompanied by a reduction of sIPSC frequency onto L2/3 pyramidal neurons.

\section{Discussion}

We demonstrate that while constitutive deletion of $\mathrm{NgR} 1$ permits both developmental OD plasticity in adults and spontaneous improvement of visual acuity, abolishing expression of NgR1 selectively within inhibitory cortical circuitry is sufficient to retain developmental OD plasticity in adulthood but does not affect visual acuity. Both constitutive deletion of NgR1 and deletion restricted to PV neurons decrease the excitatory input onto PV neurons in a specific layer of visual cortex. Thus, loss of NgR1 may alter E/I balance to retain developmental OD plasticity in adult visual cortex, but this OD plasticity is not sufficient to improve acuity following chronic deprivation, revealing that these facets of visual function are dissociable and differentially regulated by $\mathrm{NgR} 1$. different across genotypes.
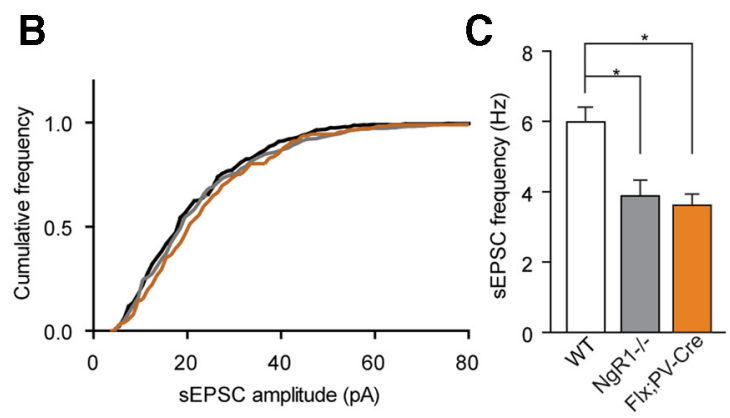

E
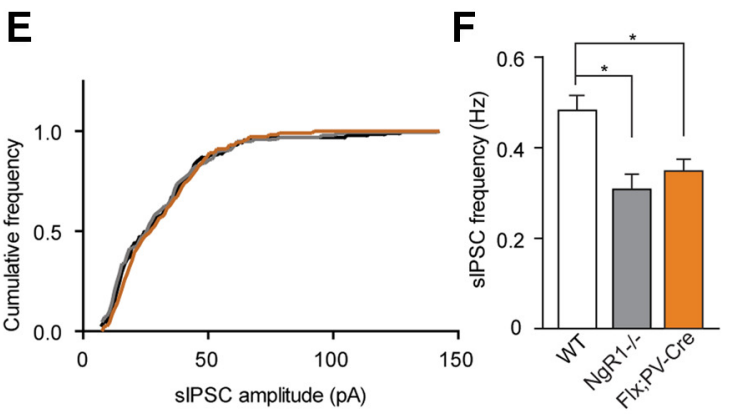

I

H
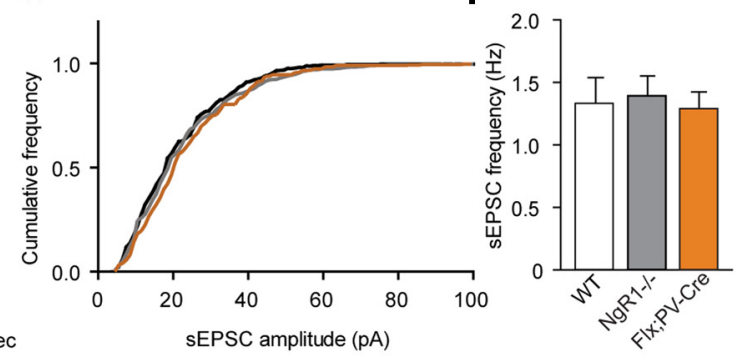

$20 \mathrm{pA}, 0.5 \mathrm{sec}$

Figure 5. Synaptic inputs onto $\mathrm{L} 2 / 3 \mathrm{PV}$ interneurons and $\mathrm{L} 2 / 3$ pyramidal neurons are altered in $\mathrm{NgR} 1^{-/-}$and $\mathrm{NgR} 1^{\mathrm{fl} / f \mathrm{fl} x} ; \mathrm{PV}$ Cre visual cortex. $A$, Representative traces of sEPSCs from L2/3 PV interneurons from WT, $\mathrm{NgR}^{-1-}$, and $\mathrm{NgR}^{\mathrm{flx} / \mathrm{flx} \text {;PV-Cre mice }}$ significantly lower in PV neurons from both $\mathrm{NgR}^{-/-}$and Flx;PV-Cre mice. $\boldsymbol{D}$, Representative traces of sIPSCs from L2/3 pyramidal neurons from WT, $\mathrm{NgR1}^{-1-}$, and Flx;PV-Cre mice. $\boldsymbol{E}$, Cumulative sIPSC amplitude distribution of sEPSCs is nearly identical be-

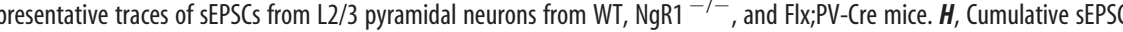
amplitude distribution is indistinguishable across genotypes. $I$, Frequency of $S E P S C S$ of $L 2 / 3$ pyramidal neurons is not significantly

The critical period for MD to affect OD and visual performance was first described in kittens (Wiesel and Hubel, 1965; Dews and Wiesel, 1970; Giffin and Mitchell, 1978; Rothblat et al., 1978; Mitchell, 1988). Subsequently, critical periods for OD plasticity have been identified in numerous mammalian species including rat, ferret, and monkey (LeVay et al., 1980; Fagiolini et al., 1994; Issa et al., 1999). Mice also exhibit a critical period for OD plasticity and the maturation of visual acuity (Gordon et al., 1996; Prusky and Douglas, 2003), as well as several characteristics of visual circuitry conserved with carnivores, including linear versus nonlinear spatial summation, contrast-invariant tuning, and selectivity for stimulus parameters such as orientation and spatial frequency (Niell and Stryker, 2008). Thus, although mice lack OD columns and possess relatively poor spatial vision, how plasticity within the circuitry of binocularity and acuity is regulated in the mouse is likely to be conserved with other mammals.

Several manipulations in rodents that promote OD plasticity after the critical period also improve visual acuity following LTMD (Levelt and Hübener, 2012). Environmental enrichment 
and dark exposure both may suppress cortical inhibition (He et al., 2006, 2007; Sale et al., 2007). Digestion of CSPGs in visual cortex removes molecular inhibitors of anatomical plasticity (Pizzorusso et al., 2002, 2006; Orlando et al., 2012), and these molecules are also required for PV interneurons to capture the transcription factor Otx2 (Sugiyama et al., 2008). Chronic administration of fluoxetine and genetic deletion of Lynx1 alter neurotransmission by serotonin and acetylcholine, respectively, to affect plasticity of binocularity and acuity (Maya Vetencourt et al., 2008; Morishita et al., 2010). These disparate interventions may antagonize a common pathway that limits experience-dependent plasticity of both OD and visual acuity in adult visual cortex.

In contrast, here we demonstrate with conditional mouse genetics that the plasticity of OD and visual acuity are separable. Whereas the constitutive NgR1 mutant $\left(\mathrm{NgR} 1^{-1-}\right)$ displays both extended developmental OD plasticity and improved acuity following LTMD, abolishing the expression of NgR1 selectively in PV neurons maintains developmental OD plasticity in the adult but does not improve visual acuity after chronic deprivation (Figs. 1, 2). This finding is consistent with preceding studies of the disparate effects of binocular deprivation on OD plasticity and acuity, as $4 \mathrm{~d}$ binocular deprivation during the critical period does not alter OD (Gordon and Stryker, 1996), but impairs visual acuity similar to LTMD (Prusky and Douglas, 2003). We propose that abnormal vision impedes the normal maturation of acuity confined to the critical period and this capacity for experience-dependent maturation is retained into adulthood in $\mathrm{NgR}^{-/-}$mice.

Yet does the developmental plasticity present in $\mathrm{NgR}^{-1-}$ mice result in a sustained sensitivity of acuity to abnormal vision? WT mice do not display a deficit in acuity if LTMD occurs after the close of the critical period. The acuity of mice 5 weeks after LTMD from P33-P51 is indistinguishable from naive mice (Prusky and Douglas, 2003). Whether WT mice might display a transient deficit in behavioral visual acuity in the first few weeks following adult LTMD has not been reported. We examined WT mice within $7 \mathrm{~d}$ following LTMD from P67-P90 and observe a transient decrease in visual acuity (WT $7 \mathrm{~d}$ post-LTMD, $0.20+0.02 \mathrm{cpd}, n=5$ ) that slowly recovers over the course of several weeks (data not shown). This transient lower visual acuity induced by LTMD in WT adult mice precluded examining whether $\mathrm{NgR} 1$ mutant mice remain selectively sensitive to adult LTMD as this deficit is independent of critical period plasticity, and the time course for recovery in adult WT mice mirrors that for improvement of acuity in $\mathrm{NgR} 1^{-/-}$mice following LTMD during development. Both constitutive deletion of the NgR1 and restricted deletion of $\mathrm{NgR} 1$ to $\mathrm{PV}$ neurons decreases excitatory drive from $\mathrm{L} 4$ onto L2/3 PV neurons and inhibitory drive onto L2/3 pyramidal neurons (Figs. 4, 5). A recent study reports that diminished excitatory drive from L4 onto L2/3 PV neurons is an early and essential component of OD plasticity (Kuhlman et al., 2013). Thus, decreased synaptic input onto $\mathrm{L} 2 / 3 \mathrm{PV}$ neurons in $\mathrm{NgR}^{-1-}$ and $\mathrm{NgR} 1^{\mathrm{fl} / \mathrm{fl} \mathrm{x}} ; \mathrm{PV}$-Cre may provide an elevated E/I balance permissive to engage OD plasticity and shift binocularity during $\mathrm{MD}$ in the adult, but is not sufficient to improve acuity after LTMD.

How NgR1 might function to limit visual acuity remains unclear. MD alters the formation and stability of both excitatory and inhibitory synaptic connections in visual cortex (Hofer et al., 2009; Chen et al., 2012; van Versendaal et al., 2012). Both the deposition of CSPGs in perineuronal nets and the distribution of myelinated fibers plateaus in L4 coincident with the closure of the critical period (Pizzorusso et al., 2002; McGee et al., 2005), and CSPGs and myelin-associated outgrowth inhibitors are both ligands for NgR1. These inhibitory ligands may function as "molecular brakes" by signaling through NgR1 to limit structural synaptic plasticity that could contribute to improving acuity after LTMD (Morishita and Hensch, 2008; Holtmaat and Svoboda, 2009). Consistent with this hypothesis, suppressing NgR1 expression in primary hippocampal neurons by RNA interference increases the formation of excitatory synapses in vitro (Wills et al., 2012), and NgR1 mutant mice have been reported to display elevated basal turnover of dendritic spines in visual cortex (Akbik et al., 2013). It would be interesting to examine whether the number of excitatory synapses made onto L2/3 PV interneurons is altered by NgR1 deletion or restoration of normal vision following LTMD may differentially affect structural synaptic plasticity in NgR1 mutant mice. Future studies will also be required to identify where NgR1 functions within visual circuitry to limit improvement of visual acuity after LTMD beyond its role in regulating OD plasticity within PV neurons.

\section{References}

Akbik FV, Bhagat SM, Patel PR, Cafferty WB, Strittmatter SM (2013) Anatomical plasticity of adult brain is titrated by nogo receptor 1 . Neuron 77:859-866. CrossRef Medline

Barrette B, Vallières N, Dubé M, Lacroix S (2007) Expression profile of receptors for myelin-associated inhibitors of axonal regeneration in the intact and injured mouse central nervous system. Mol Cell Neurosci 34: 519-538. CrossRef Medline

Carulli D, Pizzorusso T, Kwok JC, Putignano E, Poli A, Forostyak S, Andrews MR, Deepa SS, Glant TT, Fawcett JW (2010) Animals lacking link protein have attenuated perineuronal nets and persistent plasticity. Brain 133:2331-2347. CrossRef Medline

Chen JL, Villa KL, Cha JW, So PT, Kubota Y, Nedivi E (2012) Clustered dynamics of inhibitory synapses and dendritic spines in the adult neocortex. Neuron 74:361-373. CrossRef Medline

Dews PB, Wiesel TN (1970) Consequences of monocular deprivation on visual behaviour in kittens. J Physiol 206:437-455. Medline

Dickendesher TL, Baldwin KT, Mironova YA, Koriyama Y, Raiker SJ, Askew KL, Wood A, Geoffroy CG, Zheng B, Liepmann CD, Katagiri Y, Benowitz LI, Geller HM, Giger RJ (2012) NgR1 and NgR3 are receptors for chondroitin sulfate proteoglycans. Nat Neurosci 15:703-712. CrossRef Medline

Dräger UC (1978) Observations on monocular deprivation in mice. J Neurophysiol 41:28-42. Medline

Fagiolini M, Hensch TK (2000) Inhibitory threshold for critical-period activation in primary visual cortex. Nature 404:183-186. CrossRef Medline

Fagiolini M, Pizzorusso T, Berardi N, Domenici L, Maffei L (1994) Functional postnatal development of the rat primary visual cortex and the role of visual experience: dark rearing and monocular deprivation. Vision Res 34:709-720. CrossRef Medline

Fagiolini M, Fritschy JM, Löw K, Möhler H, Rudolph U, Hensch TK (2004) Specific GABAA circuits for visual cortical plasticity. Science 303:16811683. CrossRef Medline

Giffin F, Mitchell DE (1978) The rate of recovery of vision after early monocular deprivation in kittens. J Physiol 274:511-537. Medline

Gonchar Y, Burkhalter A (1997) Three distinct families of GABAergic neurons in rat visual cortex. Cereb Cortex 7:347-358. CrossRef Medline

Gordon JA, Stryker MP (1996) Experience-dependent plasticity of binocular responses in the primary visual cortex of the mouse. J Neurosci 16: 3274-3286. Medline

Gordon JA, Cioffi D, Silva AJ, Stryker MP (1996) Deficient plasticity in the primary visual cortex of alpha-calcium/calmodulin-dependent protein kinase II mutant mice. Neuron 17:491-499. CrossRef Medline

He HY, Hodos W, Quinlan EM (2006) Visual deprivation reactivates rapid ocular dominance plasticity in adult visual cortex. J Neurosci 26:29512955. CrossRef Medline

He HY, Ray B, Dennis K, Quinlan EM (2007) Experience-dependent recovery of vision following chronic deprivation amblyopia. Nat Neurosci 10: 1134-1136. CrossRef Medline

Hensch TK, Fagiolini M, Mataga N, Stryker MP, Baekkeskov S, Kash SF (1998) Local GABA circuit control of experience-dependent plasticity in developing visual cortex. Science 282:1504-1508. CrossRef Medline

Hippenmeyer S, Vrieseling E, Sigrist M, Portmann T, Laengle C, Ladle DR, Arber S (2005) A developmental switch in the response of DRG neurons to ETS transcription factor signaling. PLoS Biol 3:e159. CrossRef Medline 
Hofer SB, Mrsic-Flogel TD, Bonhoeffer T, Hübener M (2009) Experience leaves a lasting structural trace in cortical circuits. Nature 457:313-317. CrossRef Medline

Holtmaat A, Svoboda K (2009) Experience-dependent structural synaptic plasticity in the mammalian brain. Nat Rev Neurosci 10:647-658. CrossRef Medline

Huang ZJ, Kirkwood A, Pizzorusso T, Porciatti V, Morales B, Bear MF, Maffei L, Tonegawa S (1999) BDNF regulates the maturation of inhibition and the critical period of plasticity in mouse visual cortex. Cell 98:739-755. CrossRef Medline

Hubel DH, Wiesel TN (1970) The period of susceptibility to the physiological effects of unilateral eye closure in kittens. J Physiol 206:419-436. Medline

Issa NP, Trachtenberg JT, Chapman B, Zahs KR, Stryker MP (1999) The critical period for ocular dominance plasticity in the Ferret's visual cortex. J Neurosci 19:6965-6978. Medline

Katagiri H, Fagiolini M, Hensch TK (2007) Optimization of somatic inhibition at critical period onset in mouse visual cortex. Neuron 53:805-812. CrossRef Medline

Kawaguchi Y, Kubota Y (1993) Correlation of physiological subgroupings of nonpyramidal cells with parvalbumin- and calbindinD28k-immunoreactive neurons in layer $\mathrm{V}$ of rat frontal cortex. J Neurophysiol 70:387396. Medline

Kim JE, Liu BP, Park JH, Strittmatter SM (2004) Nogo-66 receptor prevents raphespinal and rubrospinal axon regeneration and limits functional recovery from spinal cord injury. Neuron 44:439-451. CrossRef Medline

Kuhlman SJ, Olivas ND, Tring E, Ikrar T, Xu X, Trachtenberg JT (2013) A disinhibitory microcircuit initiates critical-period plasticity in the visual cortex. Nature 501:543-546. CrossRef Medline

Lee JK, Kim JE, Sivula M, Strittmatter SM (2004) Nogo receptor antagonism promotes stroke recovery by enhancing axonal plasticity. J Neurosci 24:6209-6217. CrossRef Medline

LeVay S, Wiesel TN, Hubel DH (1980) The development of ocular dominance columns in normal and visually deprived monkeys. J Comp Neurol 191:1-51. CrossRef Medline

Levelt CN, Hübener M (2012) Critical-period plasticity in the visual cortex. Annu Rev Neurosci 35:309-330. CrossRef Medline

Madisen L, Zwingman TA, Sunkin SM, Oh SW, Zariwala HA, Gu H, Ng LL, Palmiter RD, Hawrylycz MJ, Jones AR, Lein ES, Zeng H (2010) A robust and high-throughput Cre reporting and characterization system for the whole mouse brain. Nat Neurosci 13:133-140. CrossRef Medline

Maurer D, Hensch TK (2012) Amblyopia: background to the special issue on stroke recovery. Dev Psychobiol 54:224-238. CrossRef Medline

Maya Vetencourt JF, Sale A, Viegi A, Baroncelli L, De Pasquale R, O'Leary OF, Castrén E, Maffei L (2008) The antidepressant fluoxetine restores plasticity in the adult visual cortex. Science 320:385-388. CrossRef Medline

McGee AW, Strittmatter SM (2003) The Nogo-66 receptor: focusing myelin inhibition of axon regeneration. Trends Neurosci 26:193-198. CrossRef Medline

McGee AW, Yang Y, Fischer QS, Daw NW, Strittmatter SM (2005) Experience-driven plasticity of visual cortex limited by myelin and Nogo receptor. Science 309:2222-2226. CrossRef Medline

Mitchell DE (1988) The extent of visual recovery from early monocular or binocular visual deprivation in kittens. J Physiol 395:639-660. Medline

Monory K, Massa F, Egertová M, Eder M, Blaudzun H, Westenbroek R, Kelsch W, Jacob W, Marsch R, Ekker M, Long J, Rubenstein JL, Goebbels S, Nave KA, During M, Klugmann M, Wölfel B, Dodt HU, Zieglgänsberger W, Wotjak CT, et al. (2006) The endocannabinoid system controls key epileptogenic circuits in the hippocampus. Neuron 51:455-466. CrossRef Medline

Morishita H, Hensch TK (2008) Critical period revisited: impact on vision. Curr Opin Neurobiol 18:101-107. CrossRef Medline

Morishita H, Miwa JM, Heintz N, Hensch TK (2010) Lynx1, a cholinergic brake, limits plasticity in adult visual cortex. Science 330:1238-1240. CrossRef Medline

Niell CM, Stryker MP (2008) Highly selective receptive fields in mouse visual cortex. J Neurosci 28:7520-7536. CrossRef Medline

Orlando C, Ster J, Gerber U, Fawcett JW, Raineteau O (2012) Perisynaptic chondroitin sulfate proteoglycans restrict structural plasticity in an integrin-dependent manner. J Neurosci 32:18009-18017, 18017a. CrossRef Medline

Pfeffer CK, Xue M, He M, Huang ZJ, Scanziani M (2013) Inhibition of inhibition in visual cortex: the logic of connections between molecularly distinct interneurons. Nat Neurosci 16:1068-1076. CrossRef Medline

Pizzorusso T, Medini P, Berardi N, Chierzi S, Fawcett JW, Maffei L (2002) Reactivation of ocular dominance plasticity in the adult visual cortex. Science 298:1248-1251. CrossRef Medline

Pizzorusso T, Medini P, Landi S, Baldini S, Berardi N, Maffei L (2006) Structural and functional recovery from early monocular deprivation in adult rats. Proc Natl Acad Sci U S A 103:8517-8522. CrossRef Medline

Prusky GT, Douglas RM (2003) Developmental plasticity of mouse visual acuity. Eur J Neurosci 17:167-173. CrossRef Medline

Prusky GT, West PW, Douglas RM (2000) Behavioral assessment of visual acuity in mice and rats. Vision Res 40:2201-2209. CrossRef Medline

Qiu S, Anderson CT, Levitt P, Shepherd GM (2011) Circuit-specific intracortical hyperconnectivity in mice with deletion of the autism-associated met receptor tyrosine kinase. J Neurosci 31:5855-5864. CrossRef Medline

Rittenhouse CD, Shouval HZ, Paradiso MA, Bear MF (1999) Monocular deprivation induces homosynaptic long-term depression in visual cortex. Nature 397:347-350. CrossRef Medline

Rothblat LA, Schwartz ML, Kasdan PM (1978) Monocular deprivation in the rat: evidence for an age-related defect in visual behavior. Brain Res 158:456-460. CrossRef Medline

Sale A, Putignano E, Cancedda L, Landi S, Cirulli F, Berardi N, Maffei L (2004) Enriched environment and acceleration of visual system development. Neuropharmacology 47:649-660. CrossRef Medline

Sale A, Maya Vetencourt JF, Medini P, Cenni MC, Baroncelli L, De Pasquale R, Maffei L (2007) Environmental enrichment in adulthood promotes amblyopia recovery through a reduction of intracortical inhibition. Nat Neurosci 10:679-681. CrossRef Medline

Scheiman MM, Hertle RW, Beck RW, Edwards AR, Birch E, Cotter SA, Crouch ER Jr, Cruz OA, Davitt BV, Donahue S, Holmes JM, Lyon DW, Repka MX, Sala NA, Silbert DI, Suh DW, Tamkins SM, Pediatric Eye Disease Investigator Group (2005) Randomized trial of treatment of amblyopia in children aged 7 to 17 years. Arch Ophthalmol 123:437-447. CrossRef Medline

Shepherd GM, Svoboda K (2005) Laminar and columnar organization of ascending excitatory projections to layer $2 / 3$ pyramidal neurons in rat barrel cortex. J Neurosci 25:5670-5679. CrossRef Medline

Shepherd GM, Pologruto TA, Svoboda K (2003) Circuit analysis of experience-dependent plasticity in the developing rat barrel cortex. Neuron 38:277-289. CrossRef Medline

Stühmer T, Puelles L, Ekker M, Rubenstein JL (2002) Expression from a Dlx gene enhancer marks adult mouse cortical GABAergic neurons. Cereb Cortex 12:75-85. CrossRef Medline

Sugiyama S, Di Nardo AA, Aizawa S, Matsuo I, Volovitch M, Prochiantz A, Hensch TK (2008) Experience-dependent transfer of Otx2 homeoprotein into the visual cortex activates postnatal plasticity. Cell 134:508-520. CrossRef Medline

van Versendaal D, Rajendran R, Saiepour MH, Klooster J, Smit-Rigter L, Sommeijer JP, De Zeeuw CI, Hofer SB, Heimel JA, Levelt CN (2012) Elimination of inhibitory synapses is a major component of adult ocular dominance plasticity. Neuron 74:374-383. CrossRef Medline

Wang X, Duffy P, McGee AW, Hasan O, Gould G, Tu N, Harel NY, Huang Y, Carson RE, Weinzimmer D, Ropchan J, Benowitz LI, Cafferty WB, Strittmatter SM (2011) Recovery from chronic spinal cord contusion after Nogo receptor intervention. Ann Neurol 70:805-821. CrossRef Medline

Webber AL, Wood J (2005) Amblyopia: prevalence, natural history, functional effects and treatment. Clin Exp Optom 88:365-375. CrossRef Medline

Weiler N, Wood L, Yu J, Solla SA, Shepherd GM (2008) Top-down laminar organization of the excitatory network in motor cortex. Nat Neurosci 11:360-366. CrossRef Medline

Wiesel TN, Hubel DH (1963) Single-cell responses in striate cortex of kittens deprived of vision in one eye. J Neurophysiol 26:1003-1017. Medline

Wiesel TN, Hubel DH (1965) Extent of recovery from the effects of visual deprivation in kittens. J Neurophysiol 28:1060-1072. Medline

Wills ZP, Mandel-Brehm C, Mardinly AR, McCord AE, Giger RJ, Greenberg ME (2012) The Nogo receptor family restricts synapse number in the developing hippocampus. Neuron 73:466-481. CrossRef Medline

Xu X, Callaway EM (2009) Laminar specificity of functional input to distinct types of inhibitory cortical neurons. J Neurosci 29:70-85. CrossRef Medline 